

\title{
THE LIFECYCLE OF THE FIRM, CORPORATE GOVERNANCE AND \\ INVESTMENT PERFORMANCE
}

Jimmy A. Saravia ${ }^{1}$

November, 2013

\begin{abstract}
According to firm lifecycle theory the agency costs of free cash flows are not transitory problems, but are a recurrent issue once firms reach a certain stage in their lifecycle. In particular, as firms mature their cash flows increase substantially while their investment opportunities decline and, to prevent retrenchment, managements need to invest in negative net present value projects. However, too much overinvestment leads to low firm valuation and potentially a hostile takeover. This paper extends firm lifecycle theory by arguing that to neutralize the threat of takeover, managements of maturing firms and their boards of directors progressively deploy antitakeover provisions which allow them to overinvest safely and prevent a decline in the size of their corporations. Firm lifecycle theory is also tested empirically. In this respect, a contribution of this paper is to develop a new empirical index that permits the identification of mature corporations with governance problems due to agency costs of free cash flows. The empirical results show that as firms mature agency costs of free cash flows increase, more antitakeover provisions are put into place and firms invest in projects with returns below their cost of capital.
\end{abstract}

KEYWORDS: Firm Life Cycle, Free Cash flows, Corporate Governance, Overinvestment

JEL CLASSIFICATION: G31, G34

\footnotetext{
${ }^{1}$ Professor, Grupo de Investigación en Banca y Finanzas, School of Economics and Finance, Center for Research in Economics and Finance (CIEF), Universidad EAFIT, Carrera 49 Número 7 Sur 50, Medellín, Colombia, e-mail: jsaravia@eafit.edu.co.
} 


\section{INTRODUCTION}

According to Agency Theory (AT) when corporations earn substantial free cash flows, growth maximizing managements will tend to invest in projects that yield returns which are lower than the firms' cost of capital (Jensen, 1986). Stated this way, the theory suggests that any firm earning significant free cash flows will likely overinvest in negative net present value projects. However, from the perspective of the lifecycle of the firm this formulation leaves out important considerations such as the expectations, held by insiders and outsiders alike, about the company's future funding needs and investment opportunities.

In particular, according to the lifecycle theory of the firm the agency costs of free cash flows are not transitory problems, but a persistent issue once firms reach a certain stage in their lifecycle (Mueller, 2003). Specifically, as firms mature their cash flows increase substantially while their investment opportunities decline, and to prevent retrenchment, growth maximizing managements find it necessary to invest in negative net present value projects. However, too much overinvestment leads to low firm valuation and potentially a hostile takeover. It is this threat of takeover that limits the amount of overinvestment undertaken by the management of the firm. On the other hand, firm lifecycle theory suggests that young firms will not overinvest even if it earns free cash flows at a particular point in time. This is because fast growing young firms usually depend on outside sources to finance their long term growth. If growth maximizing managements of young firms expect that the free cash flows will be a temporary phenomenon they will not jeopardize future growth by overinvesting in the present. Thus, firm lifecycle theory implies that the free cash flows problem will occur in mature firms but not in young corporations. In this 
sense, one contribution of this paper is to provide evidence on the investment performance of corporations over the lifecycle of the firm that is supportive of the lifecycle view.

Furthermore, this paper extends the lifecycle theory of the firm by proposing that to neutralize the threat of takeover, managements of maturing firms and their boards of directors progressively deploy more consequential antitakeover provisions which allow them to overinvest safely and prevent a pronounced decline in the size of their corporations. That is, as firms mature and the free cash flow problem becomes more pronounced, company managements and their boards of directors put into place progressively more antitakeover provisions to accommodate the overinvestments while at the same time maintaining a comfortable level of job security.

An additional contribution of this paper is to develop a new empirical index that, based on the financial characteristics of firms over their lifecycle, permits the identification of mature corporations with governance problems due to agency costs of free cash flows. As discussed below, the derivation of the index gives a clearer perspective on the fact that the agency costs of free cash flows are not a one-off problem, but are a recurrent issue once firms reach a certain stage in their lifecycle. Importantly, the latter is overlooked in the empirical literature as researchers usually employ measures of cash flows retained by management in a given fiscal year normalized by book assets (e.g. Chi and Lee, 2010; Lehn and Poulsen, 1989) or cash levels at some point in time normalized by book assets or sales (Harford et al., 2008; Ditmar and Mahrt-Smith, 2007; Jovanovic and Rousseau, 2002). Contrary to the empirical index constructed in this paper, such measures imply that the free cash flow problem can be present in a firm in a given year and disappear in the next rather than being a recurrent problem and a feature of the lifecycle of the firm. 
The rest of this paper is organized as follows: section 2 discusses firm lifecycle theory and the progressive deterioration of corporate governance over the lifecycle of the firm as evidenced by an increase in overinvestment and managerial entrenchment. Section 3 discusses the theory behind the empirical index proposed in this paper to separate young from mature companies. Section 4 discusses the econometric specifications to test the theory. Section 5, describes the data and presents the econometric results. Section 6 concludes.

\section{THE LIFECYCLE OF THE FIRM AND CORPORATE GOVERNANCE}

Figure 1 illustrates some of the key aspects of the lifecycle theory of the firm developed by Mueller (2003). The situation faced by young firms is shown on the left hand side of the figure. According to the theory, young firms are characterized by rapid growth and by the fact that the amounts needed to fund their positive net present value investment opportunities will generally exceed its internal cash flows $\left(I^{*}>C F\right)$. Hence, for young firms the shareholder-wealth-maximization policy is to procure outside capital and invest until the firm's marginal cost of capital equals the firm's marginal return on investment and pay no dividends. In this situation, shareholders will clearly be in favor of providing the means to the young firm to increase the level of investments until all positive net present value projects have been undertaken. Conversely, growth maximizing managements of young firms would not invest in negative net present value projects since future profit would be reduced and the effect would be to increase present growth at the expense of the future growth of the firm. Thus, for a young firm, managerial and stockholder interests regarding investment policy and growth coincide. This is also represented on the left hand side of Figure 1 where the growth of young firms is depicted by a solid line. As can be 
seen, for young firms growth takes place at a rate which is consistent with shareholder wealth maximization.

\section{[Insert Figure 1 here]}

On the other hand, the right hand side of Figure 1 illustrates the case of mature firms. According to lifecycle theory, as firms become older their cash flows increase enormously while their investment opportunities decline as their industry matures. As a consequence, for older firms the positive net present value investment opportunities eventually become smaller that its internal cash flows $\left(I^{*}<C F\right)$. Now, for mature firms the shareholderwealth-maximizing policy would also be to continue investing until the marginal rate of return of the firm is equal to its marginal cost of capital. However, this would involve the reduction in the size of the firm as shown by the solid line in the figure. In order to prevent a reduction in the size of the firm, firm lifecycle theory predicts that growth-maximizing managements will tend to reduce, but not totally suppress, dividend payouts as these payments diminish the quantity of resources available for growth. Instead, managements will invest the funds in negative net present value projects. Consequently, it is at this point in the lifecycle of the firm that the key agency problem of free cash flows takes place. This is depicted in Figure 1 by a dashed line representing the fact that the growth of mature firms will be higher than that of a hypothetical mature shareholder-wealth-maximizing firm.

Nevertheless, the lifecycle theory of the firm also points out that there exist mechanisms that prevent managers from overinvesting too much in negative net present value projects. The most important of these mechanisms is the threat of a takeover. If shareholder 
dissatisfaction with management is too great the stock price may plunge, and this may increase the likelihood of a takeover. Now, it is clear that in the context of U.S. institutions the managements of maturing firms and their boards of directors can neutralize the takeover threat to a certain extent by progressively deploying antitakeover provisions. Thus, in this paper we extend the lifecycle theory of the firm by suggesting that as firms mature and the free cash flow problem becomes more pronounced, company managements and their boards of directors put into place progressively more antitakeover provisions to accommodate the overinvestments while at the same time maintaining a comfortable level of job security. The implication is that as firms mature corporate governance will tend to deteriorate as reflected in managerial entrenchment and overinvestment in negative net present value projects.

In addition it is important to note that, as shown in Figure 1, despite the fact that mature firms tend to over-invest their rate of growth is much lower than that of firms in their early years. This is a consequence of reduced opportunities for internal investment in mature industries as mentioned above. Therefore, according to firm lifecycle theory it is not the fastest-growing firms that tend to over-invest for these are typically young firms with good investment opportunities. Instead, over-investment problems are likely to occur in mature firms, especially those with entrenched managements. Faced with the prospect of contracting hierarchies, reduced real salaries, lower opportunities for promotion, and even unemployment many managers will very likely look for ways to make their companies grow. The upshot is that a mature-growth-maximizing firm will undertake more investment and pay a lower dividend than a stockholder-wealth-maximizing firm with the objective of preventing retrenchment. 
Thus, it is readily apparent that the lifecycle theory of the firm provides a wealth of predictions for some of the key issues in the field of corporate finance and corporate governance that range from agency conflicts to funding and dividend policy. In this paper we will concentrate on the following testable propositions: (a) the agency costs of free cash flows are a recurrent problem for mature firms but not a characteristic problem of young firms, (b) as firms mature progressively more antitakeover provisions are put into place to accommodate overinvestment, hence (c) corporate governance deteriorates as firms mature.

\section{AN EMPIRICAL INDEX TO SEPARATE YOUNG FROM MATURE FIRMS}

We have seen that according to firm lifecycle theory the cash flows of young firms are usually too small when compared to the amounts required for investment at the optimal level. Therefore, young firms can be characterized as being dependent on their outside sources of finance to fully exploit their investment opportunities. In contrast, the cash flows of mature firms are generally larger than the amounts of cash required for investment at the optimal level. Thus, mature firms can be considered to be financially autonomous in the sense that they can fund all their investments and at the same time return part of that cash to investors in the form of dividends or stock repurchases.

However, it is also important to take into account that debt financing is not subject to the free cash flow problem. Clearly, if the firm fails to pay interest or capital it becomes bankrupt and can be liquidated. It is only the equity-holders that suffer losses from a policy

of growth maximization through overinvestment. Hence, the key issue regarding the agency costs of free cash flows is to determine when a firm is financially dependent on shareholders and when is financially autonomous from its shareholders. 
Accordingly, let us define firms that are financially dependent on shareholders as those that on most occasions have cash flows that are smaller than their investments funded with equity and retained cash flows, and consequently have to issue new shares in order to undertake the investments. Conversely, let us define firms that are financially autonomous from shareholders as those that on most occasions have internal cash flows which are greater than their levels of investments funded with equity and retained cash flows. It is in these financially autonomous firms where the agency costs of free cash flow can occur.

From the foregoing considerations, an autonomy index or "A-index" can be constructed as follows: over a number of past years immediately preceding the year in question, add up the number of times a given company has cash flows which are greater than its investments funded using new equity plus retained cash flows $(C F>\Delta E+C F-$ Dividends). Clearly, financially dependent young firms will tend to issue a substantial amount of new equity and pay no dividends so that their $C F$ will usually be smaller than their level of investments using new equity and retained cash flows. On the other hand, financially autonomous mature firms will issue very little new equity and will pay dividends, so that their $C F$ will be usually greater than their level of investments using new equity and retained cash flows. Thus, firms that are financially autonomous from their shareholders will obtain a higher score in this index relative to those that are financially dependent on their shareholders.

Now, how long a period should we consider in order to construct the A-index? Graham (2006, p. 319) suggests that in analyzing firm financial statements one should use a fairly long period in the past: 7 to 10 years "in order to iron out the frequent ups and downs of the business cycle"... and to get "a better idea of the company's earning power." Hence, the $A$ index for a given company in a given year will be constructed by adding one point for each 
year in which a company has greater cash flows than investments funded with equity plus retained cash flows over the previous 7 years. Accordingly, the A-index will range from 0 to 7 .

Importantly, the $A$-index is designed to avoid a problem present in empirical studies that measure firm age in years. Specifically, the difficulty is that some firms mature faster than average e.g. those producing intermediate goods like transistors, while others mature much more slowly e.g. those manufacturing consumer products like Coca Cola (Mueller and Yun, 1998). Hence, if one measures firm age in years there is a danger that some young firms will be classified as mature when their economic characteristics indicate they are still young, or vice-versa, mature firms could be classified as young when in fact they present all the characteristics of a mature company. This problem is illustrated in Figure 2 below.

\section{[Insert Figure 2 here]}

As can be seen, the A-index represents a better empirical index for the purpose of separating young firms from mature companies than firm age. While measuring firm age in years can lead to an erroneous classification as some firms mature faster than others, the $A$ index will classify young firms as financially dependent as long as they retain their strong growth. On the other hand, the A-index will classify mature firms as financially autonomous due to their slow growth (or even negative growth). 


\section{ECONOMETRIC SPECIFICATION}

\subsection{The "marginal q" method}

To test the propositions stated above, in this paper we will employ a procedure first proposed by Mueller and Reardon (1993) (henceforth M\&R) to measure deviations from shareholder wealth maximization as a consequence of overinvestment. In stating their method, M\&R start by defining $I_{t}$ as the investment of a firm in period $t, C F_{t+j}$ as the cash flow that the investment generates in $t+j$, and $i_{t}$ as the firm's discount rate in $t$. Thus, the present value of the investment, $P V_{t}$ can be expressed as follows:

$$
P V_{t}=\sum_{j=1}^{\infty} \frac{C F_{t+j}}{\left(1+i_{t}\right)^{j}}
$$

Then, M\&R take the $P V_{t}$ from Eq. (1) and the investment $I_{t}$, and calculate the ratio of "the pseudo permanent return $r_{t}$ to $i_{t}$," a ratio usually labelled $q_{m t}$ or "marginal q."

$$
P V_{t}=\frac{r_{t} I_{t}}{i_{t}}=q_{m t} I_{t}
$$

That is, M\&R argue that if the company had invested $I_{t}$ in a project that generated a permanent return $r_{t}$, this project would have produced the same $P V_{t}$ as in Eq. (1). The ' $q_{m t}$ ' ratio is the key statistic in M\&R's analysis; it can measure overinvestment problems of the type where free cash flows are retained and invested in negative net present value projects. Then, M\&R define the market value of the firm $M_{t}$ as

$$
M_{t}=M_{t-1}+P V_{t}-\delta_{t} M_{t-1}+\mu_{t}
$$


Where, $\delta_{t}$ is defined as the depreciation rate that the capital market appraises for the firm's total capital, and $\mu_{t}$ is the error of the market in evaluating the market value of the firm. M\&R then subtract $M_{t-1}$ from both sides of Eq. (3), replace $P V_{t}$ with $q_{m t} I_{t}$, and finally divide both sides by $M_{t-1}$ and obtain:

$$
\frac{M_{t}-M_{t-1}}{M_{t-1}}=-\delta_{t}+q_{m t} \frac{I_{t}}{M_{t-1}}+\frac{\mu_{t}}{M_{t-1}}
$$

M\&R then argue that Eq. (4) can be used to estimate $\delta_{t}$ and $q_{m t}$. To estimate Eq. (4) M\&R utilize data on the market value of each firm and its investments. They define $M_{t}$ as the sum of the market value outstanding shares of a company plus the market value of its outstanding debt. And they define investment as:

$$
I=C F-\text { Dividends }+\Delta D+\Delta E+R \& D+A D V
$$

Where $C F$ are the cash flows of the firm defined as the sum of income before extraordinary items and depreciation, and $\Delta D$ and $\Delta E$ are defined as net additions to investment funds from changes in outstanding debt and equity respectively. Moreover, M\&R argue that although $R \& D$ and advertising expenditures $A D V$ are charged to expenses (as opposed to be treated as investments in the company accounts) they are also forms of investment that can produce intangible capital which contributes to a firm's market value, and that for this reason they add them to their measure of total investment.

\section{[Insert Figure 3 here]}

Figure 3 exemplifies the M\&R equation (Eq. (4)) and its usefulness for measuring overinvestment. A marginal $\mathrm{q}$ which is smaller than one indicates that managements are investing below the firm's cost of capital. In such a case shareholders would clearly prefer 
to receive the cash in the form of dividends or stock repurchases rather than seeing it reinvested. If managements are able to repeatedly invest below the firm's cost of capital, this would evidence the investor's inability to force the managements to pay out the free cash flows.

\subsection{Specification of the investment performance equation}

Since the objective of the present econometric investigation is to determine whether overinvestment occurs as the firm matures, the following specification for marginal $\mathrm{q}$ will be estimated:

$$
q_{m t}=\beta_{0}-\beta_{1} \text { Aindex }_{i, t}-\beta_{2} \text { Eindex }_{i, t}-\beta_{3} \text { firmsize }_{i, t-1}+\beta_{4} \text { delaware }_{i, t}-\beta_{5} \text { firmage }_{i, t}
$$

Where, A-index is the index of firm financial autonomy developed above and E-index is an index of managerial entrenchment developed by Bebchuk et al. (2009). In this paper we will employ Bebchuk et al.'s index since it is constructed using a more reasoned approach than other indices available in the literature. Instead of including every single anti-takeover provision in their index, Bebchuck et al. base the inclusion of each provision on discussions with lawyers, their own personal analysis and the examination of provisions that attract opposition from institutional investors. In this way, Bebchuk et al. identify six key governance provisions: staggered boards, limits to amend by-laws, poison pills, golden parachutes, supermajority requirements for mergers, and supermajority requirements for charter amendments. The E-index is created for a given firm in a given year by assigning a point for each of the six key provisions that the firm has. Thus, the E-index ranges from 0 to 6. These two indices will be our key corporate governance determinants of marginal q. As can be seen, the coefficients have been entered in Eq. (6) with their expected a priori signs 
according to theory and previous research. The equation states that marginal $\mathrm{q}$ declines as firm financial autonomy and managerial entrenchment increase. This is because lifecycle theory predicts that as firms become more financially autonomous and more antitakeover provisions are put in place overinvestment will tend to occur and this will be reflected in a low marginal q.

Moreover, to control for other potential determinants of $q_{m t}$, additional variables are included in Eq. (6). The first of the control variables, firmsize, will be measured as the natural logarithm of the book value of total assets at the end of year $t-1$. This variable is expected to have a negative sign. This is because traditionally (i.e. before the mid-1980s in the U.S.) large firm size used to be considered enough to allow managements to substantially over-invest and yet feel secure to a large extent. However, from the point of view of managements, following the hostile takeover wave of the 1980s large firm size probably has not been considered sufficient to provide security, and therefore it is likely that this variable may be insignificant for samples taken from more recent periods. Nevertheless, it is possible that this variable may still retain some of its explanatory power and for this reason it is included in Eq. (6) as a potential determinant of marginal q.

Secondly, a control variable which takes the value of 1 if a firm is incorporated in delaware and zero otherwise is included in Eq. (6). It is expected on a priori grounds that this variable will have a positive sign. The reason is that prior work, such as that by Daines (2001), suggests that the institutional environment for firms incorporated in the state of Delaware may be more effective in restraining agency problems, in which case marginal q should be higher. 
Finally, following prior work on rates of return on investment over the lifecycle of the firm, firm age is included as a control variable in Eq. (6). This variable will be measured as the natural logarithm of the number of years since the company's incorporation. It is expected a priori and on the grounds of previous empirical research that the variable will have a negative sign (see in particular Mueller and Yun, 1998). However, it is also possible that this variable could be insignificant given that different firms have lifecycles of different length, and that consequently, the A-index may be a better empirical indicator when it comes to the task of distinguishing young firms from mature companies.

Substituting Eq. (6) into Eq. (4), including time and industry dummy variables, and simplifying the following investment performance regression equation is obtained:

$$
\begin{array}{r}
\frac{M_{i, t}-M_{i, t-1}}{M_{i, t-1}}=-\alpha+\beta_{0} \frac{I_{i, t}}{M_{i, t-1}}-\beta_{1}\left(\text { Aindex }_{i, t}\right) \frac{I_{i, t}}{M_{i, t-1}}-\beta_{2}\left(\text { Eindex }_{i, t}\right) \frac{I_{i, t}}{M_{i, t-1}}-\beta_{3}\left(\text { firmsize }_{, t-1}\right) \frac{I_{i, t}}{M_{i, t-1}} \\
+\beta_{4}\left(\text { delaware }_{, t}\right) \frac{I_{i, t}}{M_{i, t-1}}-\beta_{5}\left(\text { firmage }_{i, t}\right) \frac{I_{i, t}}{M_{i, t-1}}+\sum_{t=1}^{T-1} \theta_{t} \text { Time }_{t}+\sum_{j=1}^{J-1} \lambda_{j} \text { Industry }_{i, j}+\frac{\mu_{i, t}}{M_{i, t-1}}
\end{array}
$$

Where Time $_{t}, t=1, \ldots, T-1$ are time dummy variables, and industry $i, j, j=1, \ldots, J-1$ are industry dummy variables, while $\alpha$ is the intercept for the base or benchmark category.

Petersen (2009) has recently examined the empirical literature and provides guidance on the appropriate methods to follow when using corporate finance panel data sets. Following his work, Eq. (7) includes time dummy variables to deal with time effects. In addition standard errors clustered by firm will be used in the next section to address firm effects. Finally, since depreciation rates should vary across companies depending on the type of investments in capital assets they undertake, Eq. (7) includes industry dummy variables by assigning each company to a two digit SIC industry code (Mueller and Yurtoglu, 2000). 


\section{DATA AND ECONOMETRIC RESULTS}

\subsection{Sample selection}

The starting point our data collection is Bebchuk et al.'s (2009) E-index database. Currently, the database contains information for the years 1990, 1993, 1995, 1998, 2000, 2002, 2004 and 2006. To obtain a sample of firms with reasonably long time series of data with which to build the variables, the database was initially inspected for companies with non-missing values for the years 1990 and 2004. ${ }^{2}$ In this manner 586 companies were identified. Given that some of the companies changed names and ticker symbols, the information was matched using 8 digit CUSIPs in order to make sure that the data referred to the same company. ${ }^{3}$ Then, a search for these 586 firms was performed using Datastream and 556 firms were found. Next, banks, financial companies and certain service industries (SICs 6000 to 6999 and above 8100) were excluded because the nature of capital and investment in these industries is fundamentally different when compared to non-financial firms. This reduced the sample by 81 companies from 556 to 475 . For this final group of 475 firms the usual practice of researchers who utilize corporate governance provision indices (e.g. Gompers et al., 2003; Bebchuk et al., 2009) was followed and the observations for the years in which IRRC does not publish governance provisions data were filled in by assuming that the provisions remain unchanged in the period between IRRC publications. Given the information contained in Bebchuk's database at the time of the data collection for this paper it was possible to assign values for the 475 firm's E-indices for a period of 19

\footnotetext{
${ }^{2}$ Bebchuk et al.'s database contains two sub-samples, a no dual class stock sub-sample and a dual class stock sub-sample. Following prior research we exclude dual class stocks for the reason that in those companies "the superior voting rights may be sufficient to provide incumbents with a powerful entrenchment mechanism that renders the other entrenchment provisions relatively unimportant" (Bebchuk et al., 2009).

${ }^{3}$ CUSIP is an acronym that refers to the 8 character alphanumeric security identifier distributed by the Committee on Uniform Security Identification Procedures.
} 
years, comprising the years from 1990 to 2008. Market prices and accounting data for these companies were obtained from the Datastream database as described in the Appendix.

\subsection{Sample description and test of hypotheses for differences between means}

Table 1 provides summary statistics for the empirical variables employed in this paper. As can be seen the firms in the sample contain substantial variation in their age, size, financial autonomy, entrenchment and other variables important for testing our hypotheses in the context of firm lifecycle theory.

\section{[Insert Table 1 here]}

To further describe the sample used in this paper Table 2 below presents the values of the A-index and E-index variables sorted by firm age. Moreover, for each variable the table presents tests hypotheses for differences between the means of the youngest firms (0 to 15 years of age and 16 to 30 years age) and the means of older firms in the other time buckets. This is interesting because it helps elucidate whether mature firms earn more free cash flows than younger companies and if the managements of older firms are more entrenched. The information in the table suggests that both propositions are correct. As can be seen, older firms have higher A-indices on average than younger companies and the tests of differences between means indicate that the differences are significant at the $1 \%$ level. Moreover, the table indicates that the E-index tends to increase with firm age and that the differences between the means of the variable for young and mature firms are also statistically significant at the $1 \%$ level.

[Insert Table 2 here] 
From these results we can conclude that while younger firms depend on outside shareholders to finance investments, older firms earn free cash flows on a continuing basis which makes them largely independent from shareholders. In addition, compared to young firms older firms have more consequential antitakeover provisions put in place as measured by the E-index. Both results taken together suggest that mature firms use the free cash flows that they earn on a ongoing basis to overinvest while, on the other hand, young companies will not overinvest even if they earn free cash flows on a given year since their managements know they will have to come back to the shareholders for additional funding in the future.

Finally, correlations between the empirical variables are presented in Table 3 . It is interesting to note that the E-index presents positive and significant correlations with the $A$ index and logfirmage. This implies that as firms mature, and on average become more financially autonomous, their managements tend to deploy a larger number of consequential anti-takeover provisions. On the other hand, Table 3 shows that the A-index presents significantly negative correlations with $\left(M_{t}-M_{t-1}\right) / M_{t-1}$ and $I_{t} / M_{t-1}$. This suggests that, consistent with firm lifecycle arguments, companies with a low A-index (young firms) invest relatively more, and have a higher rate of increase in their market values when compared to firms with a higher A-index (older companies). The latter is reinforced by the fact that that logfirmage also has negative and significant correlations with $\left(M_{t}-M_{t-1}\right) / M_{t-1}$ and $I_{t} / M_{t-1}$.

[Insert Table 3 here] 
Moreover, the table shows that the A-index has a positive and significant correlation with logtotalassets and logfirmage. This implies that, consistent with firm lifecycle theory, companies with a high $A$-index are on average relatively larger and older. Finally, note the negative and statistically significant correlation between delaware and logfirmage. This suggests that the positive relationship between incorporation in Delaware and good firm performance reported by Daines (2001) may reflect that firms incorporated in Delaware are younger on average than firms incorporated elsewhere and not any corporate governance advantage of incorporating in that State.

Having elucidated that database contains firms with sufficient variation in their age, sizes and other variables for the purposes of testing the paper's hypotheses, the next subsection employs the econometric methods discussed above to test for overinvestment.

\subsection{Econometric results}

Table 4 below presents the results from estimating Eq. (7). Mueller and Yun's (1998) investigation regarding investment performance over the lifecycle of the firm is replicated in Table 4 column 1 . This column shows results obtained by (a) specifying marginal $\mathrm{q}$ as equal to an intercept plus a coefficient times the natural logarithm of firm age, (b) substituting for marginal $\mathrm{q}$ in the basic $\mathrm{M} \& \mathrm{R}$ investment performance regression equation (Eq. 4) and finally (c) estimating the parameters by OLS. Similar to Mueller and Yun's findings, the results in the table show a significantly positive intercept of 1.8002 and negative and significant coefficient for logfirmage of -0.1810 . These estimates for our sample, pertaining to the time period 1990-2008, imply that for the average firm marginal $\mathrm{q}$ 
falls below 1 (indicative of overinvestment) around 80 years after its incorporation $\left(q_{m t}=\right.$ $1.8-0.18(\ln (80))=1)$

\section{[Insert Table 4 here]}

However, as discussed above, a specification in which firm age is measured in years since firm incorporation, has some important drawbacks. The most important is that, logically, different firms will have lifecycles of different lengths when measured in years. This is the reason why the A-index was constructed. Moreover, while the presence of free cash flows is a necessary condition for overinvestment, it is not sufficient. The reason is that if management overinvests the market value of the firm may plunge and a hostile takeover may ensue (Mueller, 2003). This is why it is important to include an index of antitakeover provisions such as the E-index to determine how insulated firm management is from the takeover threat. Thus, Table 4 column 2 specifies marginal $\mathrm{q}$ as equal to an intercept plus a coefficient times the A-index plus another coefficient times the E-index. This specification is then substituted in $M \& R$ investment performance regression equation (Eq. 4) and finally the parameters are estimated by OLS. As shown in Table 4 column 2, there are significantly negative coefficients for both the A-index and the E-index at the 1 percent level. Importantly, this result is consistent with the predictions of firm lifecycle theory as it signifies that marginal q will tend to decrease as both the A-index and the $E$ index increase.

Next, Table 4 column 3 presents the results of running a regression equation which includes the preceding two kinds of measures (i.e. years since firm incorporation and firm characteristics as captured by the $A$-index and $E$-index) as a means to detect overinvestment 
problems. As can be seen, while both the A-index and the E-index coefficients remain negative and significant at the $1 \%$ level, the coefficient for the natural logarithm of firm age becomes insignificant at any conventional level. The reason for this result is that, as mentioned earlier, although it is logically to expect that firms will go through a lifecycle there is no reason to expect that the lengths of company lifecycles measured in years will be similar for the diversity of firms. Different companies produce different types of products and operate under different business conditions. For this reason this paper argues that is more effective to measure firm characteristics such as financial autonomy and managerial entrenchment directly as a means to assess firm age, than to try to determine if a firm is young or mature by using firm age measured in years.

Further, Table 4 column 4 presents the results of running a regression equation with additional control variables. Specifically, column 4 presents the results of estimating Eq. (7) where specific predictions for its coefficients are formulated. As can be seen, in this specification both the A-index and the E-index coefficients are negative as predicted and are significant at the $1 \%$ level. However, the coefficient for logfirmage although negative as expected on a priori grounds is insignificant at any conventional level. Interestingly, the coefficient for logtotalassets $\mathrm{t}_{\mathrm{t}-1}$ is negative as predicted, and it is significant at the $5 \%$ level (one tailed t-test). This provides evidence in favor of the proposition that large firm size gives managements protection from the takeover threat, and that consequently, the managements of larger firms have more leeway to overinvest than those of smaller companies. On the other hand, contrary to our expectations the coefficient for delaware is negative and insignificant at any conventional level. Thus, at least for our sample we find no evidence that the institutional environment for firms incorporated in the State of 
Delaware may be more effective in preventing agency problems as manifested by overinvestment.

Finally, Table 4 column 5 presents the results of running a more parsimonious regression equation in which marginal $\mathrm{q}$ is specified as equal to an intercept plus a coefficient times the A-index, plus another coefficient times the E-index, and finally an additional coefficient times logtotalassets $\mathrm{t}_{\mathrm{t}-1}$. As shown in the table, for this specification the intercept is significantly positive at the $1 \%$ level and the coefficients for the A-index, $E$ index and logtotalassets $\mathrm{t}_{\mathrm{t}-1}$ are significantly negative at the $1 \%$ level.

The investment performance results are further illustrated with the aid of Table 5. This table presents values for marginal q implied by the estimates in Table 4 column 5 for different combinations of the A-index and the E-index (similar results are obtained if the estimates in Table 4 column 4 are used instead). Note that in the calculations logtotalassets $_{t-1}$ is held at its mean value of 21.6287. Hence, for example, the estimates imply that the value of marginal $\mathrm{q}$ for the average firm when the A-index $=1$ and the $E$ index $=1$ equals $1.4302\left(q_{m t}=2.4793-0.069(1)-0.063(1)-0.0424(21.6287)=1.4302\right)$.

\section{[Insert Table 5 here]}

The results in Table 5 show that the values of marginal $\mathrm{q}$ for the average firm are substantially higher than 1 when firm financial autonomy as measured by the A-index is low and managerial entrenchment as measured by the E-index is also low. Specially, the table shows the highest value of marginal q of 1.5622 when the A-index and the E-index are both equal to zero. More generally, the table shows that the values of marginal q decline progressively as financial autonomy and entrenchment become more important. 
The results in Table 5 can be best interpreted with the aid of Figure 4. Marginal q equals the area under the marginal rate of return schedule (mrr) between 0 and the level of investments divided by the area under the cost of capital ( $i$ ) between 0 and the level of investments (Mueller and Yurtoglu, 2000). Thus, an estimated marginal $\mathrm{q}$ that is greater than one is consistent with the interpretation that firms are maximizing shareholder value by equalizing their marginal rates of returns to their marginal cost of capital. For example, as shown in Figure 4, if a firm invested $I_{1}$ it would equalize its marginal rate of return $\mathrm{mrr}$ to its marginal cost of capital $i$, and its marginal q would equal the area under $m r r$ from 0 to $\mathrm{I}_{1}$, that is ' $\mathrm{a}+\mathrm{b}$,' divided by the area under the marginal cost of capital curve, namely ' $\mathrm{b}$ ', which is clearly greater than one.

\section{[Insert Figure 4 here]}

Therefore, since the data indicates that marginal qs are substantially greater than one for low values of the A-index and the E-index, we conclude that there is significant evidence in favor of the hypothesis that the managements of financially dependent firms as measured by the $A$-index who are not entrenched using anti-takeover provisions as measured by the E-index (i.e. young firms) will tend to invest in a manner which is consistent with shareholder wealth maximization as measured by marginal $\mathrm{q}$.

In addition, the results in Table 5 show that the values of marginal $q$ for the average firm are close to 1 when firm financial autonomy as measured by the A-index is high and managerial entrenchment as measured by the E-index is low. For instance, the table shows a value of marginal q of 1.0162 when the $A$-index is equal to 7 and the E-index is equal to 1. 
In general, the table shows values for marginal $\mathrm{q}$ which are close to 1 in the upper-right hand region of Table 5 .

Now, an estimated $q_{m t}$ which is close to 1 can be interpreted as an indication of "moderate" overinvestment taking place. To see this suppose that a firm invests $I_{2}$ as shown in Figure 4, and moreover assume that the areas labelled ' $a$ ' and ' $d$ ' in the figure are approximately equal. In this case, marginal q would equal the area under $m r r$, that is ' $a+b$ $+c$ ', divided by the area under the cost of capital curve, i.e. ' $b+c+d$ '. Given that ' $a$ ' and 'e' have approximately equal areas, marginal q approximately equals 1 and, as the figure shows, there is overinvestment taking place as the marginal investment project has a rate of return that is below its cost of capital.

Therefore, the estimates of marginal q presented in Table 5 are consistent with the hypothesis that the managements of financially autonomous firms as measured by the $A$ index who are not entrenched using anti-takeover provisions as measured by the E-index will tend to over-invest moderately as measured by marginal q. Note that overinvestment is "moderate" for the case of these mature firms because of the threat of takeover.

Furthermore, the results shown in Table 5 indicate that there is strong evidence of overinvestment as measured by marginal $\mathrm{q}$ when both the A-index and the E-index have high values. From the previous discussion it is clear that no firm that maximizes shareholder wealth would undertake investment for which $q_{m t}<1$, for this unequivocally implies overinvestment. Now, when the $A$-index $=7$ and the E-index $=6$ the marginal q implied by the estimates of Table 4 column 5 equals 0.7012 . This suggests that on average for every dollar that firms with these high levels of financial autonomy and entrenchment 
invested during the period 1990-2008, the market value of these firms increased by only about $\$ 0.70$. Consequently, the estimates of marginal q presented in Table 5 are consistent with the hypothesis that the managements of mature financially autonomous firms as measured by the A-index who are also entrenched using anti-takeover provisions as measured by the E-index will tend to over-invest substantially as measured by marginal q.

Finally, the results in Table 5 show that the values of marginal $\mathrm{q}$ for the average firm are substantially greater than 1 when firm financial autonomy as measured by the A-index is low and managerial entrenchment as measured by the E-index is high. For instance, the table shows a value of marginal q of 1.2472 when the $A$-index is equal to 0 and the $E$-index is equal to 5. This suggests that on average for every dollar that firms with these levels of low financial autonomy and high entrenchment invested during the period 1990-2008, the market value of these firms increased by about $\$ 1.25$. In general, the table shows values for marginal $\mathrm{q}$ which are greater than 1 in the lower-left hand side region of Table 5. Hence, the estimates of marginal q presented in Table 5 are consistent with the hypothesis that the managements of financially dependent firms as measured by the A-index who are also entrenched using anti-takeover provisions as measured by the E-index will tend to invest in a manner consistent with shareholder wealth maximization as measured by marginal q. In other words, if there are no free cash flows there can be no overinvestment even though the management of the firm is entrenched. However, this does not rule out that there may be other agency problems involved that cause the managements of these firms to keep antitakeover provisions in place. ${ }^{4}$

\footnotetext{
${ }^{4}$ I discuss and examine this issue empirically elsewhere. I conclude that these companies are mature firms that have lost their financial autonomy but that would not remove their antitakeover provisions due to their prior investments in unrelated businesses which makes them potential hostile takeover targets (Saravia, 2010).
} 


\section{CONCLUSION}

The agency costs of free cash flows are a problem which is characteristic of mature firms. As firms mature their cash flows eventually become larger than the amounts needed to fund all positive net present value projects. If it is taken into consideration that some mature firms need to retrench, it is not surprising that their managements will employ some of the free cash flows to mitigate the negative growth. Faced with the option between overinvesting and firing workers, they will likely choose the more popular route. The lifecycle theory of the firm and the derivation of the A-index give a clearer perspective on this fact.

The A-index contrasts with current measurements of free cash flows in that it makes it clear that the agency costs of free cash flows are a recurrent problem for mature firms and a feature of the lifecycle of the firm. The A-index compares the size of the cash flows with the actual investments undertaken using equity and retained earnings rather than solely measuring the size of the retained cash flows or the level of cash held by a corporation at some point in time. In this sense, the contribution of this paper has been to develop a new empirical index that allows us to separate young from mature firms more effectively than using chronological firm age.

Finally, firm lifecycle theory and the results in this paper leads us to conclude that, assuming that the objective of a policy maker is to improve corporate governance in the sense that managers remain responsive to the wishes of the shareholders, there is only one effective policy to be implemented: to outlaw the deployment of anti-takeover provisions. If this policy were implemented over-investment on the part of mature corporations would be mitigated to a moderate level. The reason is that if shareholder dissatisfaction with 
management were to become too great the stock price would plunge, and this would increase the likelihood of a takeover. Thus, management would be under increasing pressure to pay out the funds to shareholders in the form of dividends or stock repurchases rather than over-investing.

\section{APPENDIX}

Table A.1 lists the sources of data used in this paper. The first column of the table displays the data items used, while the second column presents the data sources. Panel A presents the data needed to compute the market value of a firm at the end of year $t\left(M_{t}\right)$, which in turn is required to implement the Mueller and Reardon (1993) marginal q method. Specifically, the table shows that $M_{t}$ is computed by adding the market value of common stock (wc05301 x P) plus the book value of total debt (wc03255) and preferred stock (wc03451). ${ }^{5}$ Where the market value common stock is calculated by multiplying the end of fiscal year number of shares (wc05301) times the end of fiscal year price per share (P).

\section{[Insert Table A.1 here]}

On the other hand, Panel B lists the data needed to calculate the investment of a firm over year $\mathrm{t}\left(I_{t}\right)$ which is also necessary to implement the M\&R marginal q method. In particular, $I_{t}$ is calculated by first subtracting dividends (wc04551) from cash flows (wc04201) and then adding net new equity (the change in the number of shares wc05301 times average share price $\mathrm{P}$ over year $t$ ), net new debt (the change in total debt wc03255 over year $t$ ), R\&D expenditures (wc01201), and advertising expenses (estimated by multiplying total sales (wc01001) and advertising to sales ratios taken from IRS reports on

\footnotetext{
${ }^{5}$ Datastream datatypes are presented in parenthesis.
} 
corporation returns, see Mueller and Yurtoglu, 2000). Moreover, Panel C lists the sources of data for Bebchuk et al.'s (2009) E-index, the companies' dates of incorporation which is used to compute firm age, as well as the book value of total assets.

The financial data utilized to compute the autonomy index are also taken from Table A.1. As discussed previously, the A-index is calculated by adding one point for each year in which a company has greater cash flows than investments financed using equity and retained cash flows during the previous 7 years. Investments in financed using equity and retained cash flows $\left(I_{e}\right)$ are measured as follows:

$$
I_{e}=C F-\text { Dividends }+\Delta E
$$

Where $C F$ is the cash flow of the firm (wc04201), Dividends are taken from Datastream (wc04551) and $\Delta E$ stands for net new equity. Therefore, when calculating the $A$-index for a given firm in year $t, 1$ point is added for every year (from $t-7$ to $t-1$ ) in which $C F>I_{e}$. Finally note that prior to the calculation of the M\&R variables all items were deflated by using the CPI $(2000=1)$. The CPI data for the U.S. were obtained from the World Bank, World Development Indicators, ESDS International, University of Manchester. 


\section{REFERENCES}

Bebchuk, L., A. Cohen, and A. Ferrel. 2009. What Matters in Corporate Governance? The Review of Financial Studies 22: 783-827.

Chi, J. D., and D. S. Lee. 2010. The Conditional Nature of the Value of Corporate Governance. Journal of Banking \& Finance 34: 350-361.

Daines, R. 2001. Does Delaware Law Improve Firm Value? Journal of Financial Economics 62 (3): 525-558.

Dittmar, A., and J. Mahrt-Smith. 2007. Corporate Governance and the Value of Cash Holdings. Journal of Financial Economics 83: 599-634.

Gompers, P., J. Ishii, and A. Metrick. 2003. Corporate Governance and Equity Prices. Quarterly Journal of Economics 118: 107-155.

Graham, B. 2006. The Intellingent Investor. Rev. Ed. New York: Collins Business Essentials.

Harford, J., S. Mansi, and W. F. Maxwell. 2008. Corporate Governance and Firm Cash Holdings. Journal of Financial Economics 87: 535-555.

Jensen, M. 1986. Agency Costs of Free Cash Flow, Corporate Finance, and Takeovers. American Economic Review 76: 323-329.

Jovanovic, B., and P. L. Rousseau. 2002. The Q-Theory of Mergers. American Economic Review 92: 198-204. 
Lehn, K., and A. Poulsen. 1989. Free Cash Flow and Stockholder Gains in Going Private Transactions. Journal of Finance 44: 771-787.

Mergent, Inc. 2004. Mergent Industrial Manual. Vol. 1 \& 2. New York: Mergent.

Mueller, D. C. 2003. The Corporation: Investments, Mergers and Growth. London and New York: Routledge.

Mueller, D. C., and E. A. Reardon. 1993. Rates of Return on Corporate Investment. Southern Economic Journal 60: 430-453.

Mueller, D. C., and S. L. Yun. 1998. Rates of Return over the Firm's Lifecycle. Industrial and Corporate Change 7: 347-368.

Mueller, D. C., and B. Yurtoglu. 2000. Country Legal Environments and Corporate Investment Performance. German Economic Review 1: 187-220.

Petersen, M. A. 2009. Estimating Standard Errors in Finance Panel Data Sets: Comparing Approaches. The Review of Financial Studies 22: 435-480.

Saravia, J. A. 2010. An Investigation of the Relationship between Corporate Governance and Firm Performance. University of Surrey, U.K., Unpublished PhD Thesis. 


\section{Table 1. Summary Statistics}

This table provides summary statistics for the variables employed in this paper. A-index is a firm-level index of financial autonomy computed by adding one point for every year, in the previous 7 years, in which a given firm's cash flows are greater than its investment financed using equity and retained cash flows. E-index is the entrenchment index created by Bebchuk et al. (2009). $\left(M_{t}-M_{t-1}\right) / M_{t-1}$ is the percentage change in the market value of the firm between the end of year $t-1$ and the end of year $t$. $I_{t} / M_{t-1}$ is the investment undertaken by a given firm during year $t$ divided by the market value of the firm at the end of year $t-1$. logtotalassets is the natural logarithm of the book value of total assets measured at the end of year $t-1$ in US\$. delaware is a dummy variable that takes the value of 1 if a firm is incorporated in Delaware and zero otherwise. logfirmage is the natural logarithm of firm age measured in years since the company's incorporation.

\begin{tabular}{lcccccc}
\hline Variable & $\mathrm{N}$ & Mean & Median & Std. Dev. & Min & Max \\
\hline A-index & 8687 & 5.0199 & 6 & 2.1651 & 0 & 7 \\
E-index & 8687 & 2.6594 & 3 & 1.3638 & 0 & 6 \\
$\left(M_{t}-M_{t-1}\right) / M_{t-1}$ & 8620 & 0.0807 & 0.0309 & 0.3454 & -0.8363 & 4.5065 \\
$I_{t} M_{t-1}$ & 8639 & 0.1262 & 0.0942 & 0.1607 & -0.7120 & 2.2021 \\
logtotalassets $t_{t-1}$ & 8686 & 21.6287 & 21.5468 & 1.4726 & 17.2768 & 27.2513 \\
delaware & 8687 & 0.4649 & 0 & 0.4988 & 0 & 1 \\
logfirmage & 8687 & 4.0373 & 4.2195 & 0.6085 & 0.0000 & 5.0752 \\
\hline
\end{tabular}




\section{Table 2. Financial autonomy and managerial entrenchment over the lifecycle of the firm}

This table presents the means and standard deviations of the A-index and E-index variables sorted by firm age. The A-index is a firm-level index of financial autonomy computed by adding one point for every year, in the previous 7 years, in which a given firm's cash flows are greater than its investment financed using new equity and retained cash flows. The E-index is the entrenchment index created by Bebchuk et al. (2009). Firm age is the company's age measured in years since its incorporation. In addition, for the $A$-index and $E$-index variables, the table tests hypotheses for differences between the means of the youngest firms ( 0 to 15 years as well as 16 to 30 years of age) and the means of older firms in the other time buckets. * and ** indicate that the difference is significant at the $1 \%$ and $5 \%$ level respectively (one tailed t-tests).

\begin{tabular}{|c|c|c|c|c|c|c|c|c|c|c|}
\hline \multirow{2}{*}{ Firm age } & \multicolumn{5}{|c|}{ A-index } & \multicolumn{5}{|c|}{ E-index } \\
\hline & $N$ & Mean & Std. Dev. & Diff. 0-15yrs & Diff. 16-30yrs & $N$ & Mean & Std. Dev. & Diff. 0-15yrs & Diff. 16-30yrs \\
\hline 0 to 15 years & 358 & 2.5419 & 2.3933 & & & 358 & 2.0196 & 1.4151 & & \\
\hline 16 to 30 years & 997 & 3.5757 & 2.3800 & $-1.0338 *$ & & 997 & 2.3019 & 1.3942 & $-0.2823^{*}$ & \\
\hline 31 to 45 years & 1235 & 4.4121 & 2.3583 & $-1.8702 *$ & $-0.8364 *$ & 1235 & 2.5870 & 1.3933 & $-0.5674 *$ & $-0.2851 *$ \\
\hline 46 to 60 years & 1114 & 4.7271 & 2.1890 & $-2.1852^{*}$ & $-1.1514^{*}$ & 1114 & 2.7136 & 1.3682 & $-0.694 *$ & $-0.4117 *$ \\
\hline 61 to 75 years & 1471 & 5.4317 & 1.9390 & $-2.8898 *$ & $-1.856^{*}$ & 1471 & 2.6139 & 1.3574 & $-0.5943 *$ & $-0.312 *$ \\
\hline 76 to 90 years & 1560 & 5.9314 & 1.4570 & $-3.3895^{*}$ & $-2.3557^{*}$ & 1560 & 2.7423 & 1.3393 & $-0.7227 *$ & $-0.4404 *$ \\
\hline 91 to 105 years & 1198 & 5.7362 & 1.5470 & $-3.1943^{*}$ & $-2.1605^{*}$ & 1198 & 2.9332 & 1.2421 & $-0.9136^{*}$ & $-0.6313^{*}$ \\
\hline 106 to 120 years & 445 & 5.7371 & 1.5218 & $-3.1952 *$ & $-2.1614^{*}$ & 445 & 3.0090 & 1.3237 & $-0.9894 *$ & $-0.7071 *$ \\
\hline 121 to 135 years & 154 & 5.4545 & 1.9607 & $-2.9126^{*}$ & $-1.8788 *$ & 154 & 2.9935 & 1.1289 & $-0.9739 *$ & $-0.6916^{*}$ \\
\hline 136 to 150 years & 122 & 5.9508 & 0.9435 & $-3.4089 *$ & $-2.3751^{*}$ & 122 & 2.7377 & 1.2779 & $-0.7181 *$ & $-0.4358 *$ \\
\hline 151 to 165 years & 33 & 5.5758 & 1.1997 & $-3.0339 *$ & $-2.0001 *$ & 33 & 2.8788 & 1.139 & $-0.8592 *$ & $-0.5769^{*}$ \\
\hline
\end{tabular}




\section{Table 3. Correlation matrix}

This table presents the correlation matrix for the variables employed in this paper. A-index is a firm-level index of financial autonomy computed by adding one point for every year, in the previous 7 years, in which a given firm's cash flows are greater than its investment financed using equity and retained earnings. E-index is the entrenchment index created by Bebchuk et al. (2009). $\left(M_{t}-M_{t-1}\right) / M_{t-1}$ is the percentage change in the market value of the firm between the end of year $t-1$ and the end of year $t . I_{t} / M_{t-1}$ is the investment undertaken by a given firm during year $t$ divided by the market value of the firm at the end of year $t-1$. logtotalassets is the natural logarithm of the book value of total assets measured at the end of year $t-1$ in US\$. delaware is a dummy variable that takes the value of 1 if a firm is incorporated in Delaware and zero otherwise. logfirmage is the natural logarithm of firm age measured in years since the company's incorporation. * and ** indicate that a correlation is significant at the $1 \%$ and $5 \%$ level respectively.

\begin{tabular}{|c|c|c|c|c|c|c|c|}
\hline Variable & A-index & E-index & $\left(M_{t}-M_{t-1}\right) / M_{t-1}$ & $I_{t} / M_{t-1}$ & $\begin{array}{l}\text { logtotal- } \\
\text { assets }_{t-1}\end{array}$ & delaware & logfirmage \\
\hline A-index & 1.0000 & & & & & & \\
\hline E-index & $0.0503^{*}$ & 1.0000 & & & & & \\
\hline$\left(M_{t}-M_{t-1}\right) / M_{t-1}$ & $-0.1224^{*}$ & $-0.0698^{*}$ & 1.0000 & & & & \\
\hline$I_{t} / M_{t-1}$ & $-0.1419^{*}$ & 0.0095 & $0.5219 *$ & 1.0000 & & & \\
\hline logtotalassets $_{t-1}$ & $0.1014 *$ & $-0.0790 *$ & $-0.0844 *$ & $-0.0945^{*}$ & 1.0000 & & \\
\hline delaware & $-0.1363^{*}$ & $-0.1307^{*}$ & $0.0419^{*}$ & $0.0774 *$ & $0.0340^{*}$ & 1.0000 & \\
\hline logfirmage & $0.4158 *$ & $0.1533^{*}$ & $-0.1231^{*}$ & $-0.1145^{*}$ & $0.2344 *$ & $-0.2388^{*}$ & 1.0000 \\
\hline
\end{tabular}




\section{Table 4. Investment performance over the lifecycle of the firm}

This table presents estimates of 'marginal q' for firms in the paper's database over the time period from 1990 to 2008. The technique employed was originally developed by Mueller and Reardon (1993). The estimation method is OLS. The dependent variable is $\left(M_{t}-M_{t-1}\right) / M_{t-1}$, which is the percentage change in the market value of the firm between the end of year $t-1$ and the end of year $t . I_{t} / M_{t-l}$ is the investment undertaken by a given firm during year $t$ divided by the market value of the firm at the end of year $t-1$. $A$-index is a firm-level index of financial autonomy computed by adding one point for every year, in the previous 7 years, in which a given firm's cash flows are greater than its investment financed using equity and retained cash flows. E-index is the entrenchment index created by Bebchuk et al. (2009). logtotalassets $_{\mathrm{t}-1}$ is the natural logarithm of the book value of total assets measured at the end of year $t-1$ in US\$. delaware is a dummy variable that takes the value of 1 if a firm is incorporated in Delaware and zero otherwise. logfirmage is the natural logarithm of firm age measured in years since the company's incorporation. The regressions include year dummy variables to pick up movements in stock market values which are common to all firms. Moreover, each company is assigned to a two digit SIC industry code and industry dummy variables are also included. * and ** indicate that the coefficient is significant at the $1 \%$ and $5 \%$ level respectively (one tailed t-test). Following Petersen (2009) standard errors clustered by firm are reported in parentheses.

\begin{tabular}{|c|c|c|c|c|c|}
\hline Variable & $(1)$ & (2) & (3) & (4) & (5) \\
\hline \multirow[t]{2}{*}{$I_{t} / M_{t-1}$} & $1.8002^{*}$ & $1.5942 *$ & $1.7184 *$ & $2.5330^{*}$ & $2.4793^{*}$ \\
\hline & $(0.2679)$ & $(0.1146)$ & $(0.2409)$ & $(0.4451)$ & $(0.4514)$ \\
\hline \multirow[t]{2}{*}{$\left(\right.$ logfirmage $\left.e_{t}\right) I_{t} / M_{t-1}$} & $-0.1810^{*}$ & & -0.0392 & -0.0352 & \\
\hline & $(0.0640)$ & & $(0.0566)$ & $(0.0608)$ & \\
\hline \multirow[t]{2}{*}{$\left(A-\right.$ index $\left._{t}\right) I_{t} / M_{t-1}$} & & $-0.0740 *$ & $-0.0694 *$ & $-0.0664 *$ & $-0.0690^{*}$ \\
\hline & & $(0.0146)$ & $(0.0144)$ & $(0.0144)$ & $(0.0149)$ \\
\hline \multirow[t]{2}{*}{$\left(E\right.$-index $\left.{ }_{t}\right) I_{t} / M_{t-1}$} & & $-0.0616^{*}$ & $-0.0586^{*}$ & $-0.0636^{*}$ & $-0.0630^{*}$ \\
\hline & & $(0.0202)$ & $(0.0198)$ & $(0.0206)$ & $(0.0211)$ \\
\hline \multirow[t]{2}{*}{$\left(\right.$ logtotalassets $\left._{\mathrm{t}-1}\right) I_{t} / M_{t-1}$} & & & & $-0.0374 * *$ & $-0.0424 *$ \\
\hline & & & & $(0.0218)$ & $(0.0201)$ \\
\hline \multirow[t]{2}{*}{$\left(\right.$ delaware $\left._{t}\right) I_{t} / M_{t-I}$} & & & & -0.0559 & \\
\hline & & & & $(0.0583)$ & \\
\hline Industry dummy variables? & yes & yes & yes & yes & yes \\
\hline Time dummy variables? & yes & yes & yes & yes & yes \\
\hline Adjusted $\mathrm{R}^{2}$ & 0.3523 & 0.3616 & 0.3616 & 0.3628 & 0.3626 \\
\hline Number of observations & 8618 & 8618 & 8618 & 8618 & 8618 \\
\hline
\end{tabular}


Table 5. Calculated $q_{m s}$ for different combinations of the A-index and the E-index

This table presents values for marginal q implied by the estimates in Table 4 column 5 for different combinations of the A-index and the E-index. A-index is a firm-level index of financial autonomy computed by adding one point for every year, in the previous 7 years, in which a given firm's cash flows are greater than its investment financed using equity and retained earnings. E-index is the entrenchment index created by Bebchuk et al. (2009). Note that in the calculations logtotalasset $_{\mathrm{t}-1}$, the natural logarithm of the book value of total assets measured at the end of year t-1 in US\$, is held at its mean value of 21.6287 .

\begin{tabular}{|c|c|c|c|c|c|c|c|c|c|}
\hline & & \multicolumn{8}{|c|}{$A$-index } \\
\hline \multirow{8}{*}{ 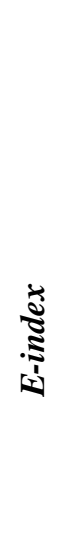 } & & 0 & 1 & 2 & 3 & 4 & 5 & 6 & 7 \\
\hline & 0 & 1.5622 & 1.4932 & 1.4242 & 1.3552 & 1.2862 & 1.2172 & 1.1482 & 1.0792 \\
\hline & 1 & 1.4992 & 1.4302 & 1.3612 & 1.2922 & 1.2232 & 1.1542 & 1.0852 & 1.0162 \\
\hline & 2 & 1.4362 & 1.3672 & 1.2982 & 1.2292 & 1.1602 & 1.0912 & 1.0222 & 0.9532 \\
\hline & 3 & 1.3732 & 1.3042 & 1.2352 & 1.1662 & 1.0972 & 1.0282 & 0.9592 & 0.8902 \\
\hline & 4 & 1.3102 & 1.2412 & 1.1722 & 1.1032 & 1.0342 & 0.9652 & 0.8962 & 0.8272 \\
\hline & 5 & 1.2472 & 1.1782 & 1.1092 & 1.0402 & 0.9712 & 0.9022 & 0.8332 & 0.7642 \\
\hline & 6 & 1.1842 & 1.1152 & 1.0462 & 0.9772 & 0.9082 & 0.8392 & 0.7702 & 0.7012 \\
\hline
\end{tabular}




\section{Table A.1. Data sources}

This table lists the main sources of data used in this paper. Panel A shows the data items needed to compute the market value of a firm at the end of year $t$. Panel B lists the data items needed to calculate the investment of a firm over year $t$. Panel $\mathrm{C}$ lists the sources of data for important items such as Bebchuk et al.'s (2009) E-index, as well as date of incorporation which is used to compute firm age.

\begin{tabular}{|c|c|}
\hline $\begin{array}{l}\text { Panel A. Firm market value }\left(M_{t}\right) \\
\text { Data item }\end{array}$ & Datastream datatype \\
\hline Market value of common stock & $($ wc05301 x P) \\
\hline End of fiscal year number of shares & wc05301 \\
\hline End of fiscal year price per share & $\mathrm{P}$ \\
\hline Book value of total debt & wc03255 \\
\hline Preferred stock & $\mathrm{wc} 03451$ \\
\hline \multicolumn{2}{|l|}{ Panel B. Investment $\left(I_{t}\right)$} \\
\hline Data item & Datastream datatype/ other \\
\hline Cash flow & wc04201 \\
\hline Dividends & $\mathrm{wc} 04551$ \\
\hline Net new debt $=$ change in total debt during year & change in wc03255 \\
\hline $\begin{array}{l}\text { Net new equity }=\text { change in number of common } \\
\text { shares outstanding } \mathrm{x} \text { average share price over year } t\end{array}$ & change in wc05301 $\mathrm{x}$ average $\mathrm{P}$ \\
\hline R\&D expenditures & wc01201 \\
\hline \multicolumn{2}{|l|}{ Advertising expenses } \\
\hline $\begin{array}{l}\text { Approximated by multiplying company sales by } \\
\text { advertising to sales ratios from the IRS reports } \\
\text { on corporation returns for } 1995 \text {. }\end{array}$ & $\begin{array}{l}\text { IRS reports on corporation } \\
\text { returns. Table 6: Balance } \\
\text { sheets, income statements, tax } \\
\text { and selected other items. See } \\
\text { Mueller and Yurtoglu (2000). }\end{array}$ \\
\hline Total sales & wc01001 \\
\hline \multicolumn{2}{|l|}{ Panel C. Other } \\
\hline Data item & Datastream datatype/ other \\
\hline Total assets & wc02999 \\
\hline Date of fiscal period end & wc05350 \\
\hline Consumer price index (CPI) & $\begin{array}{l}\text { World bank - world } \\
\text { development indicators }\end{array}$ \\
\hline Entrenchment index (E-index) & $\begin{array}{l}\text { Available from Bebchuk's } \\
\text { webpage at http:// www. } \\
\text { law.harvard.edu /faculty/ } \\
\underline{\text { bebchuk/data.shtml }}\end{array}$ \\
\hline Date of Incorporation (to compute firm age) & $\begin{array}{l}\text { Mergent Industrial Manual } \\
\text { (Mergent, 2004) }\end{array}$ \\
\hline Industry SIC codes & $\begin{array}{l}\text { 'Eqy Sic Code' } \\
\text { (Bloomberg table wizzard) }\end{array}$ \\
\hline State of incorporation & $\begin{array}{l}\text { 'State Of Incorporation' } \\
\text { (Bloomberg table wizzard) }\end{array}$ \\
\hline
\end{tabular}




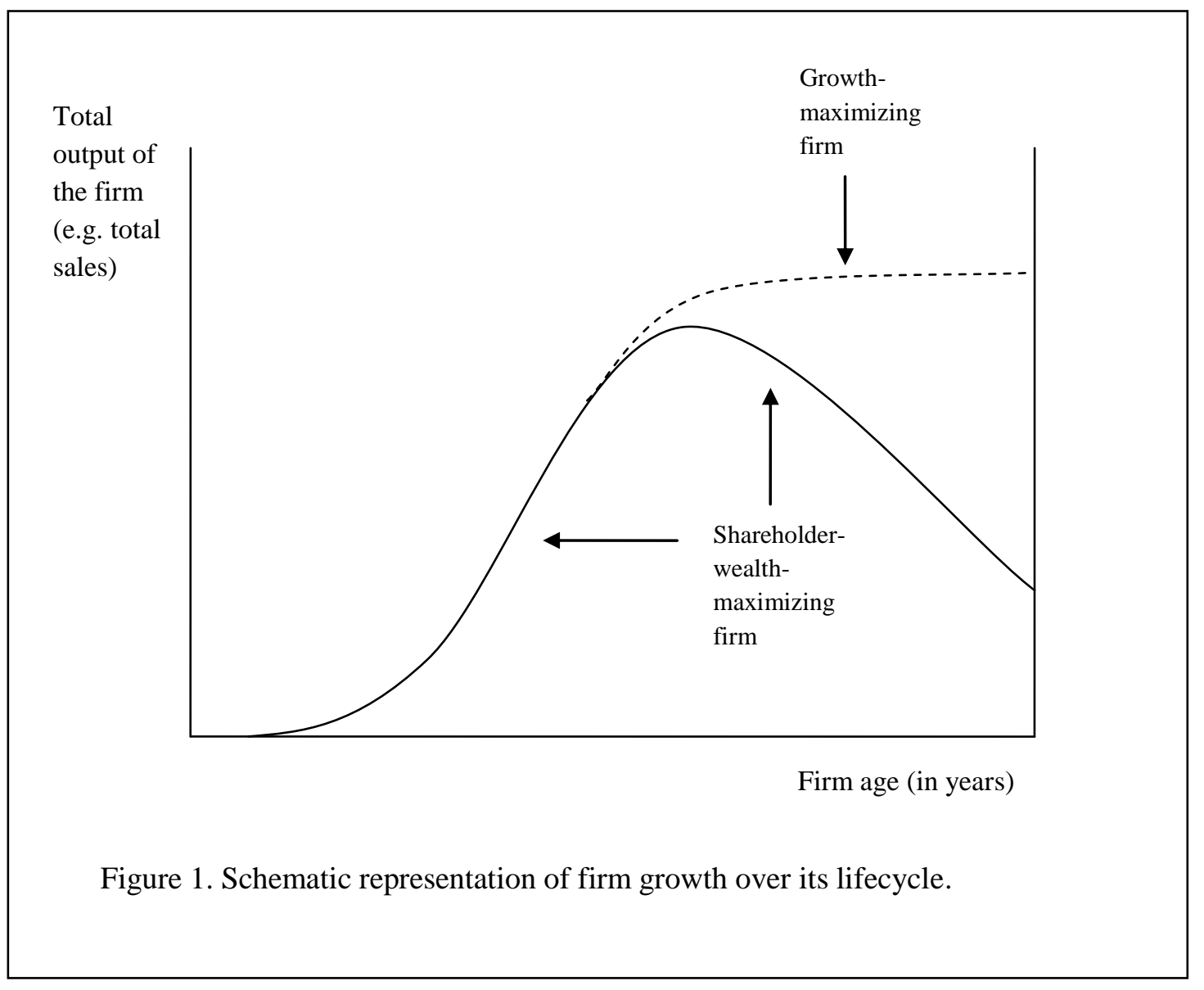




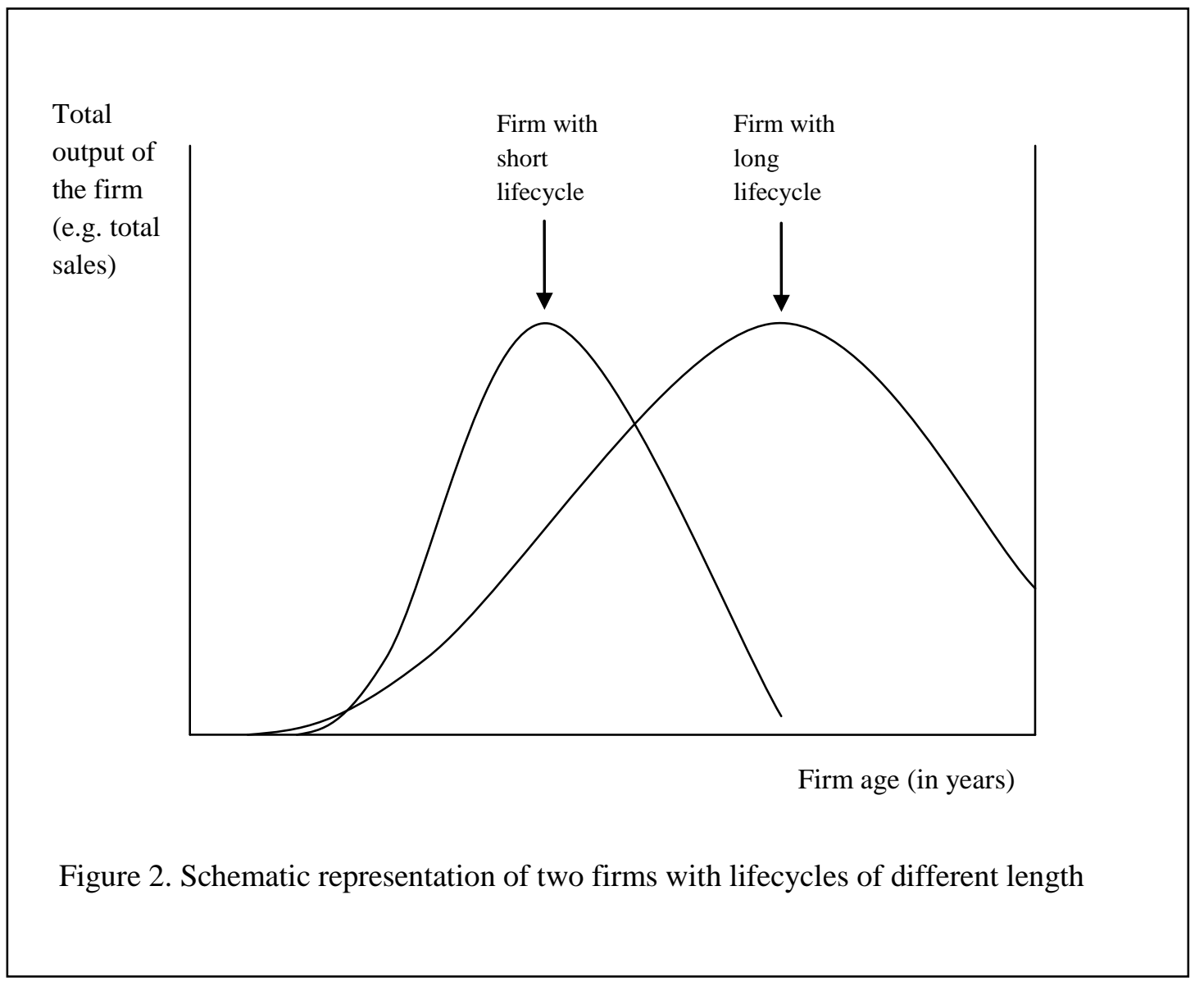




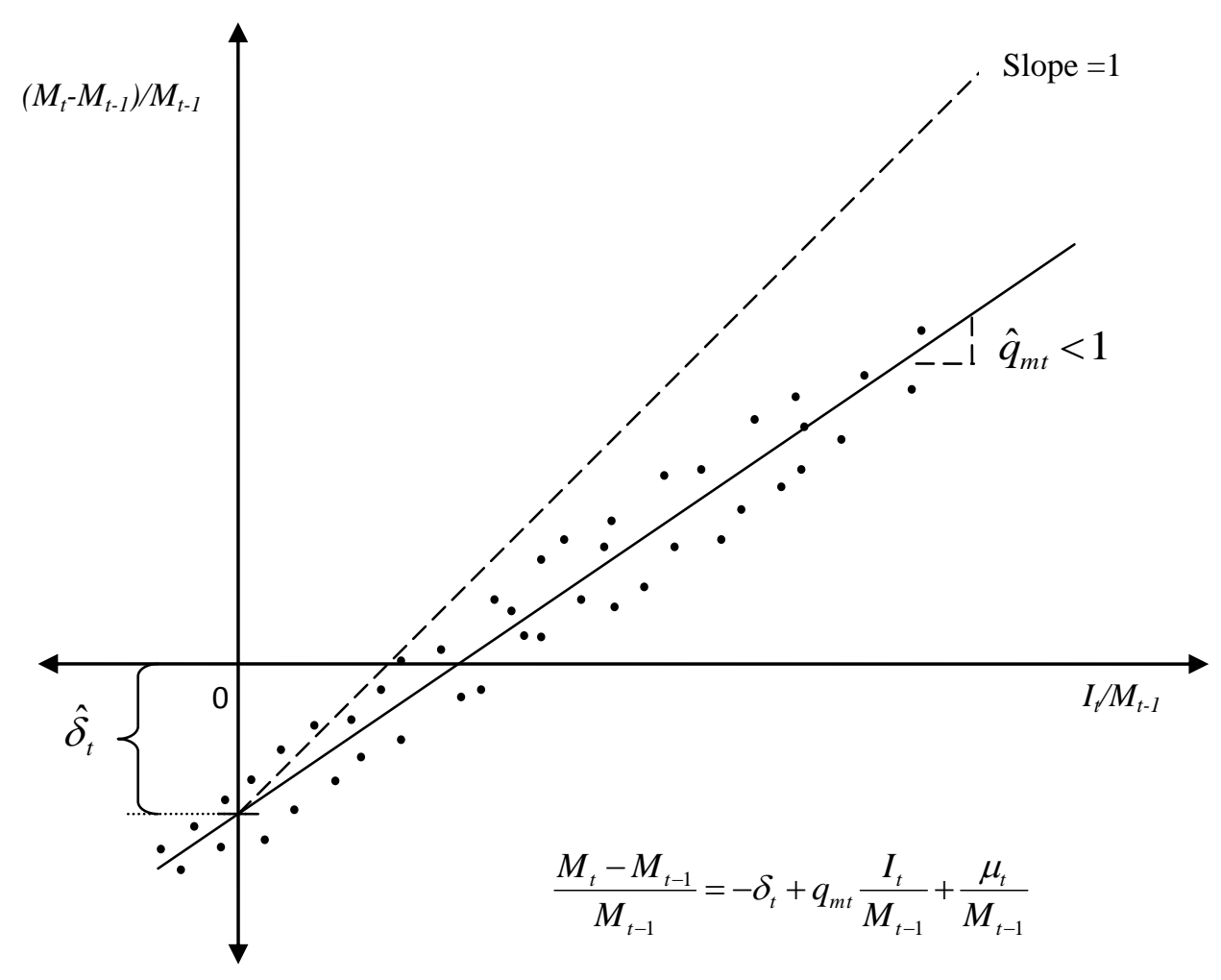

Fig. 3. The M\&R model -an example of an overinvestment situation. Source: adapted from Mueller and Reardon (1993) 


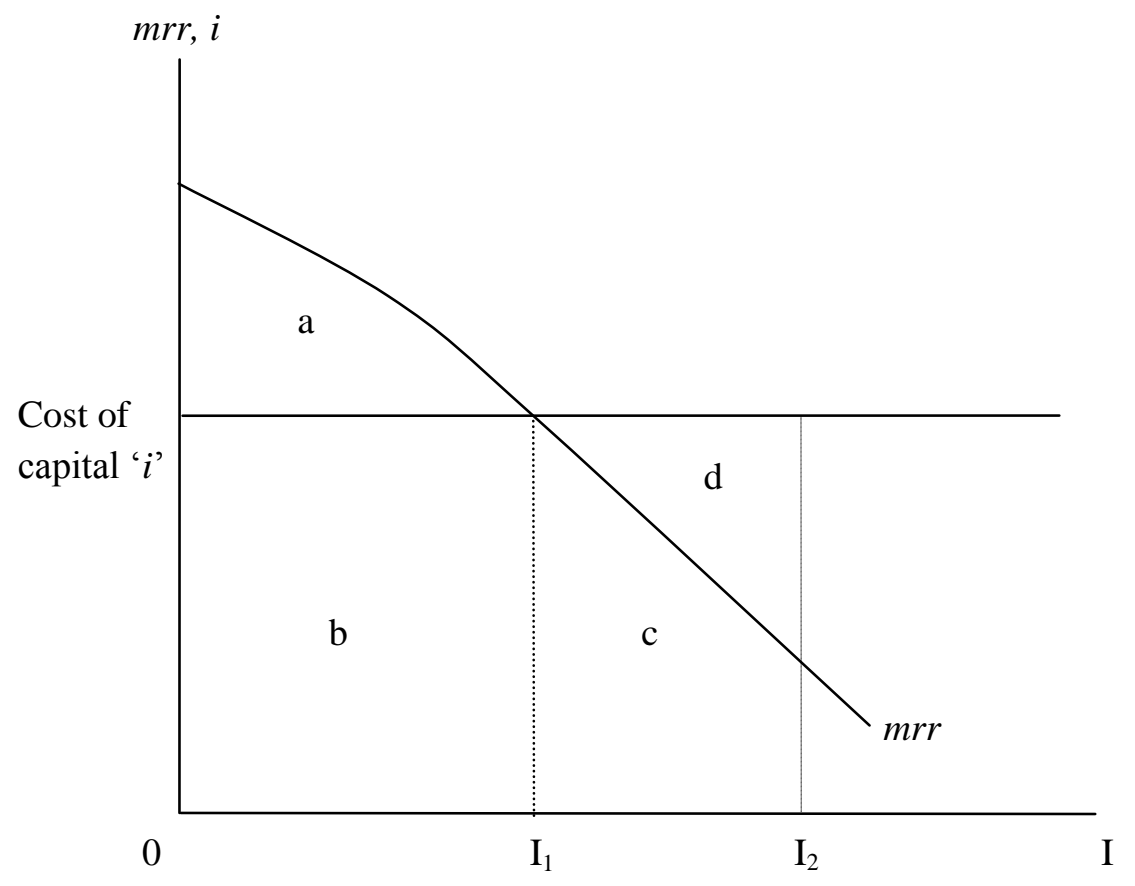

Fig. 4. Interpretation of marginal q results. 